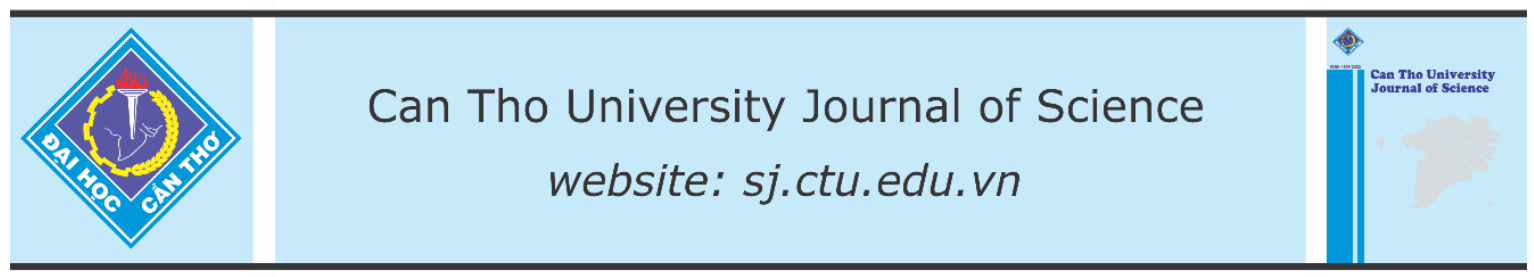

DOI: 10.22144/ctu.jen.2020.010

\title{
Acute toxicity, antibacterial and antioxidant abilities of Elephantopus mollis H.B.K. and Elephantopus scaber L.
}

Nguyen Trong Hong Phuc ${ }^{1 *}$, Phan Thanh Dat ${ }^{2}$, Nguyen Thi Thuy Nhien ${ }^{3}$, Phung Thi Hang ${ }^{1}$ and Do Tan Khang ${ }^{3}$

${ }^{1}$ School of Education, Can Tho University, Vietnam

${ }^{2}$ Master student majored in Ecology, course 25, Can Tho University

${ }^{3}$ Biotechnology Research and Development Institute, Can Tho University, Vietnam

*Correspondence: Nguyen Trong Hong Phuc (email: nthphuc@ctu.edu.vn)

\section{Article info.}

Received 25 Feb 2020

Revised 18 May 2020

Accepted 31 Jul 2020

\section{Keywords}

Acute toxicity, antibacterial, antioxidation, Elephantopus mollis H.B.K., Elephantopus scaber $L$.

\begin{abstract}
Elephantopus mollis H.B.K. and Elephantopus scaber L. were collected at To mountain in An Giang province and assessed for extraction efficiency, resistance ability to common bacterial strains in humans and animals, antioxidation, and toxicity. The extraction efficiency of two species was 11$26 \%$ and 16-28\%, respectively and depending on the part of the plant. The flowers of both species had better antioxidant results than other parts with $E C_{50}$ at $32.2051 \mu \mathrm{g} / \mathrm{mL}$ and $59.9778 \mu \mathrm{g} / \mathrm{mL}$, respectively, which was highly different from the rest of the plant $(p<0.05)$. The leaves of both species had higher antibacterial properties than the other parts. For the six bacterial strains tested, both studied species had the strongest inhibiting ability for the growth of E. coli. (at a concentration of $200 \mathrm{mg} / \mathrm{mL}$ ) different from that of Ampicillin ( $p<0.05)$. These two species were not toxic to Mus musculus at the dose of $8,000 \mathrm{mg} / \mathrm{Kg}$.
\end{abstract}

Cited as: Phuc, N.T.H., Dat, P.T., Nhien, N.T.T., Hang, P.T. and Khang, D.T., 2020. Acute toxicity, antibacterial and antioxidant abilities of Elephantopus mollis H.B.K. and Elephantopus scaber L.. Can Tho University Journal of Science. 12(2): 9-14.

\section{INTRODUCTION}

Vietnam, a fast developing country (MOHA and UNFPA, 2015), has been had a strong expansion of non-communicable diseases, rich-poor gap issues, conservation of natural resources and the environment (Bui et al., 2016). Overuse of medicine and stimulant, long-term exposure to toxic chemicals and environmental pollution make the multiple cases of non-communicable diseases such as liver diseases, diabetes, cardiovascular and cancer more and more increasing (Budnik et al., 2018). On the other hand, differences in economic conditions as well as health care system in urban and rural have led people to choose different medicines use. Lowincome people in rural areas often choose folk remedies to treat high-cost illnesses such as cancer or diabetes (Campbell-Lendrum and Prüss-Ustün, 2018). Therefore, the use and development of natural medicine from the plants locally sourced are increasingly important (Do Huy Bich et al., 2006). Traditional herbal remedies used to prevent and treat diseases are almost common worldwide (Scartezzini and Speroni, 2000; Oliver, 2013; Gall et al., 2018). Generally traditional medical system 
may indicate safety, but no efficacy of treatments, especially in herbal medicine where tradition is almost completely based on remedies containing active principles at very low and ultra-low concentrations. Even, many people have been relying on magical-energetic principles. Hence, clinical administration is the pharmacological activity that has been applied based on conventional laboratory techniques and clinical trials (Firenzuoli and Gori, 2007). In Vietnam, many valuable herbs mentioned in folk remedies or scientific documents have been studied at various levels (Pham Hoang Ho, 2003; Vo Van Chi, 2012). Elephantopus genus includes perennial tree species, common in hot and humid climates ( $\mathrm{La}$ Dinh Moi et al., 2005). These are herbaceous species with many therapeutic uses in traditional remedies, especially liver diseases such as acute viral hepatitis and cirrhosis (Do Huy Bich et al., 2006; Vo Van Chi, 2012). In Vietnam, two species of Elephantopus have been recorded as Elephantopus mollis H.B.K. and Elephantopus scaber L. with relatively similar morphology, especially in the dry form (Pham Hoang Ho, 2003; Vo Van Chi, 2012). This may cause confusion for users when collecting or treating the disease (Do Tat Loi, 2004; Vo Van

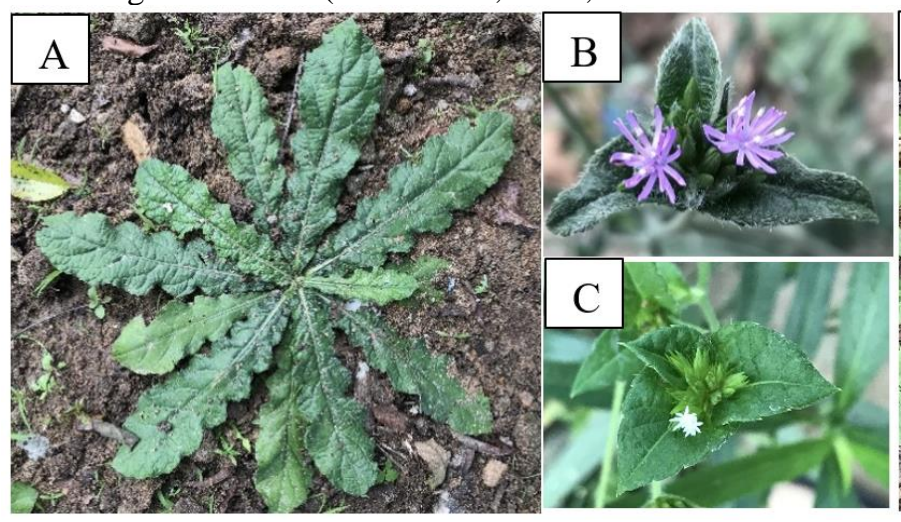

Chi, 2012). Studying the toxicity, antibacterial and antioxidant abilities of these two species locally is necessary to compare the pharmacological efficacy of the two species for considering their potential in clinical practice.

\section{METHODOLOGY}

\subsection{Experimental materials}

Experimental materials were E. mollis and E. scaber collected at To mountain - An Giang province at the time of flowering (Figure 1). The experimental material was determined according to the classification system of plants in the Vietnamese herb book (Pham Hoang Ho, 2003). Parts of the plant including the roots, stems, leaves, flowers, and the whole plant were dried and ground into powder. Twenty-five grams of medicinal powder was boiled in $100^{\circ} \mathrm{C}$ water for 1 hour (1:30 ratio) with three replicates. Base on the method of Truong et al. (2018), the extract was then collected, cooled, filtered and heated directly to a viscous form, followed by drying at $60^{\circ} \mathrm{C}$ to a constant mass to obtain the crude extract which was stored at $4^{\circ} \mathrm{C}$ for further experiment.

Fig. 1: Morphology of E. scaber (A and B) and E. mollis (C and D)

\subsection{Antioxidant assay}

The capability of root, stems, leaves, flowers and the whole plant extracts of the two species to scavenge 2,2-diphenyl-1-picrylhydrazyl (DPPH) radical was determined according to the method of Aquino et al. (2001) with some modifications. The reaction mixture consisted of $40 \mu \mathrm{L}$ DPPH $(1,000 \mu \mathrm{g} / \mathrm{mL})$ and $960 \mu \mathrm{L}$ extract. The reaction mixture was incubated in the dark at room temperature for 20 minutes. $\mathrm{Ab}$ sorbance was then measured at $515 \mathrm{~nm}$ with UVVIS color spectrophotometer (Labomed, USA). Percentage inhibits free radicals compared to Vitamin $\mathrm{E}$ (Sigma Aldrich). $\mathrm{EC}_{50}$ value is calculated based on linear equation of Vitamin $\mathrm{E}$ and extracts.

\subsection{Antibacterial assay}

The antibacterial activity of the extract was determined based on the formation of aseptic ring around the well with the extract by the method of Parkavi et al. (2012) and Nguyen Thi Ai Lan et al. (2019) with some modifications. The bacterial strains used in the experiment were: Listeria monocytogenes, Staphylococcus aureus, Bacillus cereus, Bacillus subtilis, Salmonella spp. and Escherichia coli. Ampicillin at a dose of $0.001 \mathrm{mg} / \mathrm{mL}$ was used as positive control. Each bacterium was tested with three replicates corresponding to extracts of each plant organ of the two herbs. These were prepared in five concentrations of 
$10,50,100,150$, and $200 \mathrm{mg} / \mathrm{mL}$. The samples were incubated for 24 hours at room temperature.

\subsection{Acute toxicity experiment}

Toxicity of the two species extract was tested based on OECD 420 model for 96 hours according to the regulations of the Vietnamese Ministry of Health (2015) on Mus musculus white mouse $(23.6 \pm 2.1$ g/individual). Each experimental concentration was assigned to 10 individuals with a starting dose of 5 $\mathrm{mg} / \mathrm{kg}$ and ended at $8,000 \mathrm{mg} / \mathrm{kg}$.

\subsection{Statistics}

The empirical data is managed and processed by IBM SPSS Statistic 22.0 (IBM, USA). Interaction between plant parts and concentration treatments in assessing antibacterial and antioxidant capacity was assessed by comparing two-factor variance method by Duncan post-hoc at $95 \%$ confidence.

\section{RESULTS AND DISCUSSION}

\subsection{Extraction efficiency}

E. mollis and E. scaber had high extraction efficiency. From $25 \mathrm{~g}$ of medicinal powder from different parts, leaves of $E$. mollis showed the highest extraction efficiency, which was statistically different from the rest of the plant $(p<0.05)$. Meanwhile, $E$. scaber stems and leaves were both capable of achieving high extraction efficiency.

The extraction performance of the two species was significantly higher (E. mollis: $11-32 \%$, E. scaber: $15-28 \%$ ) in comparison with some other species such as Caesalpinia sappan L. (6.8\%) (Nguyen Tan
Dat and Ba Tiep Nguyen, 2016), Streptocaulon juventas Merr. (3.35\%) (Dai Thi Xuan Trang et al., 2015) or Helicteres hirsuta L. with the highest efficiency of 9.96\% (Tran Van Tien and Thi Mai Huong Vo, 2017).

Table 1: Extraction performance of parts of $E$. mollis and E. scaber

\begin{tabular}{llr}
\hline Parts of the plant & N & Ratio \pm SD (\%) \\
\hline E. mollis root & 3 & $13.0 \pm 1.1^{\mathrm{a}}$ \\
E. mollis stem & 3 & $11.1 \pm 0.8^{\mathrm{a}}$ \\
E. mollis leaves & 3 & $25.8 \pm 1.2^{\mathrm{cd}}$ \\
E. mollis flower & 3 & $18.5 \pm 0.6^{\mathrm{b}}$ \\
E. mollis & 3 & $32.3 \pm 0.5^{\mathrm{e}}$ \\
E. scaber root & 3 & $24.1 \pm 1.4^{\mathrm{c}}$ \\
E. scaber stem & 3 & $28.5 \pm 0.8^{\mathrm{d}}$ \\
E. scaber leaves & 3 & $27.7 \pm 0.6^{\mathrm{d}}$ \\
E. scaber flower & 3 & $15.8 \pm 0.8^{\mathrm{b}}$ \\
E. scaber & 3 & $18.4 \pm 1.4^{\mathrm{b}}$ \\
\hline
\end{tabular}

Means ratio $\pm S D$ have the same letter are not significantly different (Duncan, $p>0.05$ ).

\subsection{Antioxidation}

E. mollis flowers had the best antioxidant capacity, in which, at a concentration of $70 \mu \mathrm{g} / \mathrm{mL}$, the extract was able to eliminate $92 \%$ of free radicals (Figure 2). The flowers of E. scaber also showed high antioxidant capacity, in which, at a concentration of 70 $\mu \mathrm{g} / \mathrm{mL}$, the flower of $E$. scaber was also able to reduce $61 \%$ free radicals. E. scaber root showed the weakest resistance, at a dose of $700 \mu \mathrm{g} / \mathrm{mL}$, that could only reduce $53 \%$ of free radicals.

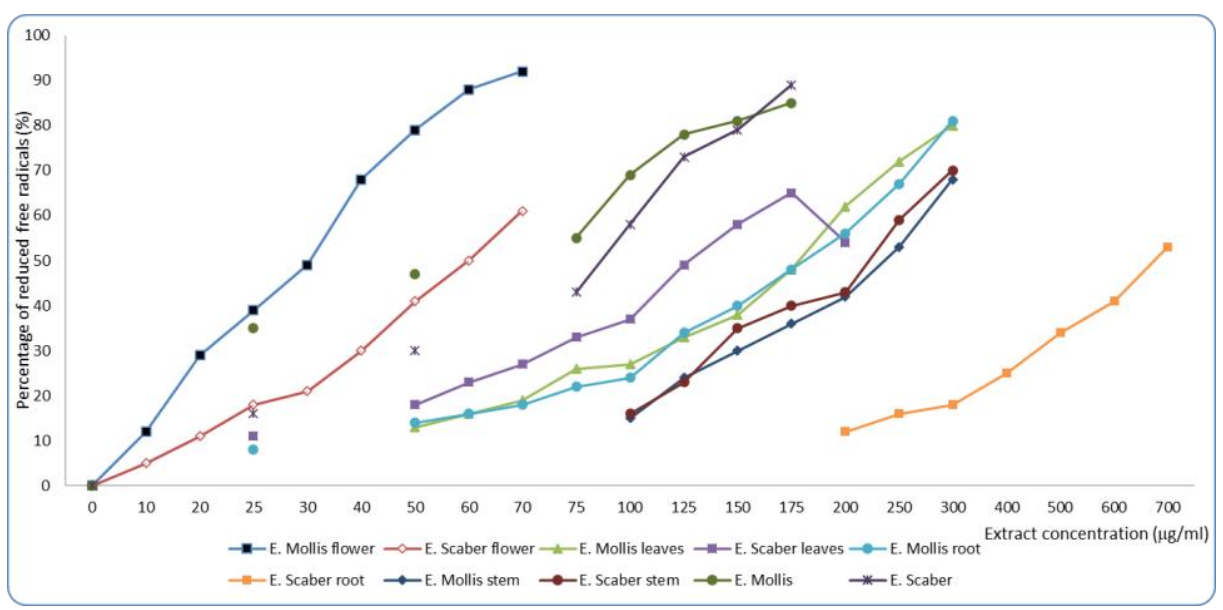

Fig. 2: Antioxidant ability of E. mollis and E. scaber

When analyzing $\mathrm{EC}_{50}$ value, flowers of the two species both showed high antioxidant ability, at 32.2 $\mu \mathrm{g} / \mathrm{mL}, 50 \%$ of free radicals can be removed (Table 2 ). The antioxidant capacity of E. mollis flower was
2.62 times lower than that of Vitamin E but higher than that of other herbal plants which are considered to have high antioxidant capacity such as Streptocaulon juventas $\left(\mathrm{EC}_{50} 349.35 \mu \mathrm{g} / \mathrm{mL}\right.$ ) (Dai Thi 
Xuan Trang et al., 2015), Morinda citrifolia $\left(\mathrm{EC}_{50}\right.$ $1025.2 \mu \mathrm{g} / \mathrm{mL}$ ) (Dai Thi Xuan Trang et al., 2012), or Solanum hainanense ( $\left.\mathrm{EC}_{50} 1734 \mu \mathrm{g} / \mathrm{mL}\right)$ (Nguyen and Eun, 2011).

Table 2: Antioxidant activity of $E$. mollis and $E$. scaber

\begin{tabular}{lcrr}
\hline Parts of plant & $\mathbf{n}$ & $\begin{array}{r}\mathbf{E C}_{\mathbf{5 0}} \\
(\boldsymbol{\mu} \mathbf{g} / \mathbf{m L})\end{array}$ & $\mathbf{R}^{\mathbf{2}}$ \\
\hline E. mollis flowers & 72 & 32.2051 & 0.9721 \\
E. mollis leaves & 63 & 183.5357 & 0.9690 \\
E. mollis stem & 63 & 219.2174 & 0.9678 \\
E. mollis root & 72 & 185.8889 & 0.9797 \\
E. mollis & 72 & 153.3182 & 0.8776 \\
E. scaber flowers & 72 & 59.9778 & 0.9555 \\
E. scaber leaves & 63 & 132.0789 & 0.9759 \\
E. scaber stem & 63 & 218.0800 & 0.9443 \\
E. scaber root & 72 & 751.1429 & 0.9309 \\
E. scaber & 72 & 105.2353 & 0.9675 \\
Vitamin E & 72 & 12.3349 & 0.9695 \\
\hline
\end{tabular}

Compared with other medicinal plants in the same family or genus, E. mollis showed higher antioxidant capacity than Silybum marianum $\left(\mathrm{EC}_{50} 39\right.$ $\mu \mathrm{g} / \mathrm{mL}$ ) (Mhamdi et al., 2016) and E. tomentosus $\left(\mathrm{EC}_{50} 887 \mu \mathrm{g} / \mathrm{mL}\right.$ ) (Yam et al., 2008). The antioxidant capacity of $E$. scaber is lower than $S$. marianum but higher than other species listed above, especially flowers of E. scaber.

\subsection{Antibacterial ability}

According to statistical analysis, the higher the extract concentration was, the greater the antibacterial activity was (Duncan, $p<0.05$ ). Leaf extract of both research species showed high antibacterial capacity against Gram-positive bacteria (Bacillus cereus, Bacillus subtilis, Staphylococcus aureus, Listeria monocytogenes) that was better than the positive control, Ampicillin. For Salmonella spp., a gram-negative one, both species showed very good resistance, statistically significant difference compared to Ampicillin (Duncan, $p<0.05$ ). As for E. coli, Ampicillin showed the highest resistance $(p<0.05)$. However, resistance to E. coli of E. mollis and E. scaber is highest compared to resistance to other bacteria, with antibacterial rings of up to $28.3 \pm 1.5 \mathrm{~mm}$ and $27.0 \pm 1.0 \mathrm{~mm}$, respectively (Table 3 ).

Table 3: Antibacterial ability of two species of Elephantopus

\begin{tabular}{|c|c|c|c|c|c|c|}
\hline \multirow{2}{*}{ Parts of plant } & \multicolumn{6}{|c|}{ Antimicrobial ring diameter $(\mathrm{mm})$} \\
\hline & B. cereus & B. subtilis & S. aureus & L. monocytogenes & E. coli & Salmonella \\
\hline \multicolumn{7}{|l|}{ E. mollis } \\
\hline Neg-control & $6.0 \pm 0.0^{\mathrm{a}}$ & $6.0 \pm 0.0^{\mathrm{a}}$ & $6.0 \pm 0.0^{\mathrm{a}}$ & $6.0 \pm 0.0^{\mathrm{a}}$ & $6.0 \pm 0.0^{\mathrm{a}}$ & $6.0 \pm 0.0^{\mathrm{a}}$ \\
\hline Root & $9.7 \pm 0.6^{c}$ & $11.3 \pm 0.6^{\mathrm{c}}$ & $8.7 \pm 1.5^{\mathrm{b}}$ & $9.7 \pm 0.6^{\mathrm{b}}$ & $15.0 \pm 1.7^{b}$ & $12.3 \pm 0.6^{\mathrm{c}}$ \\
\hline Stem & $8.3 \pm 0.6^{\mathrm{b}}$ & $9.0 \pm 1.7^{\mathrm{b}}$ & $8.3 \pm 1.5^{\mathrm{b}}$ & $8.3 \pm 0.6^{\mathrm{b}}$ & $15.0 \pm 0.0^{\mathrm{b}}$ & $11.3 \pm 0.6^{\mathrm{c}}$ \\
\hline Leaf & $19.3 \pm 1.2^{\mathrm{f}}$ & $24.0 \pm 1.0^{\mathrm{f}}$ & $19.7 \pm 0.6^{\mathrm{e}}$ & $23.0 \pm 1.0^{\mathrm{e}}$ & $28.3 \pm 1.5^{\mathrm{e}}$ & $23.3 \pm 1.2^{\mathrm{f}}$ \\
\hline Flower & $13.0 \pm 1.0^{\mathrm{d}}$ & $16.3 \pm 2.1^{\mathrm{d}}$ & $14.7 \pm 0.6^{c}$ & $16.7 \pm 0.6^{\mathrm{c}}$ & $26.7 \pm 0.6^{\mathrm{d}}$ & $16.3 \pm 0.6^{\mathrm{d}}$ \\
\hline Whole plant & $15.3 \pm 0.6^{\mathrm{e}}$ & $19.3 \pm 0.6^{\mathrm{e}}$ & $16.7 \pm 1.2^{\mathrm{d}}$ & $19.0 \pm 1.0^{\mathrm{d}}$ & $25.3 \pm 0.6^{\mathrm{c}}$ & $19.0 \pm 1.0^{\mathrm{e}}$ \\
\hline Pos-control & $7.7 \pm 0.6^{\mathrm{b}}$ & $10.0 \pm 1.1 b^{c}$ & $14.7 \pm 1.2^{\mathrm{c}}$ & $24.5 \pm 2.2^{\mathrm{e}}$ & $32.4 \pm 1.1^{\mathrm{f}}$ & $9.7 \pm 1.0^{\mathrm{b}}$ \\
\hline \multicolumn{7}{|l|}{ E. scaber } \\
\hline$\overline{\text { Neg-control }}$ & $6.0 \pm 0.0^{\mathrm{a}}$ & $6.0 \pm 0.0^{\mathrm{a}}$ & $6.0 \pm 0.0^{\mathrm{a}}$ & $6.0 \pm 0.0^{\mathrm{a}}$ & $6.0 \pm 0.0^{\mathrm{a}}$ & $\overline{6.0 \pm 0.0^{\mathrm{a}}}$ \\
\hline Root & $7.3 \pm 0.6^{\mathrm{b}}$ & $8.0 \pm 0.0^{\mathrm{b}}$ & $6.3 \pm 0.6^{\mathrm{a}}$ & $7.3 \pm 0.6^{b}$ & $9.3 \pm 0.6^{b}$ & $10.0 \pm 0.0^{\mathrm{b}}$ \\
\hline Stem & $7.7 \pm 0.6^{\mathrm{b}}$ & $11.7 \pm 0.6^{\mathrm{c}}$ & $8.3 \pm 1.2^{\mathrm{b}}$ & $9.7 \pm 1.2^{\mathrm{c}}$ & $12.3 \pm 0.6^{\mathrm{c}}$ & $9.7 \pm 0.6^{b}$ \\
\hline Leaf & $16.7 \pm 1.2^{\mathrm{e}}$ & $18.7 \pm 1.5^{\mathrm{e}}$ & $18.3 \pm 1.2^{\mathrm{e}}$ & $17.7 \pm 0.6^{\mathrm{e}}$ & $27.0 \pm 1.0^{\mathrm{f}}$ & $21.0 \pm 2.0^{\mathrm{e}}$ \\
\hline Flower & $10.3 \pm 1.2^{\mathrm{d}}$ & $14.0 \pm 2.6^{\mathrm{d}}$ & $11.3 \pm 0.6^{\mathrm{c}}$ & $18.0 \pm 1.0^{\mathrm{e}}$ & $22.3 \pm 1.5^{\mathrm{e}}$ & $17.7 \pm 2.5^{\mathrm{d}}$ \\
\hline Whole plant & $9.0 \pm 0.0^{\mathrm{c}}$ & $11.0 \pm 1.0^{\mathrm{c}}$ & $10.7 \pm 0.6^{\mathrm{c}}$ & $11.7 \pm 0.6^{\mathrm{d}}$ & $15.3 \pm 0.6^{\mathrm{d}}$ & $12.0 \pm 1.7^{\mathrm{c}}$ \\
\hline Pos-control & $7.3 \pm 0.6^{\mathrm{b}}$ & $10.2 \pm 1.1^{\mathrm{c}}$ & $13.3 \pm 1.0^{\mathrm{d}}$ & $22.9 \pm 1.0^{\mathrm{f}}$ & $31.9 \pm 1.0^{\mathrm{g}}$ & $9.6 \pm 0.8^{b}$ \\
\hline
\end{tabular}

The mean \pm standard deviations with the same letter in the same column (corresponding to each species) are not significantly different (Duncan, $p>0.05$ ).

\subsection{Possibility of acute toxicity}

Experimental mice were poisoned with a starting dose of $5 \mathrm{mg} / \mathrm{kg}$ and gradually increased to 50,300 , $2,000,4,000$ and $8,000 \mathrm{mg} / \mathrm{kg}$. The results showed that at the experimental treatment up to 8,000 $\mathrm{mg} / \mathrm{kg}$, equivalent to $200 \mathrm{mg} / \mathrm{mouse}(25 \mathrm{~g}$ ), the mice still did not die. The Median lethal dose $\left(\mathrm{LD}_{50}\right)$ was unidentified. Comparing with Vietnamese Ministry of Health's reference to clinical drug trials (Ministry of Health, 2015), the two experimental herb species were non-toxic to tested mice and has the potential to undertake clinical studies in humans. 


\section{CONCLUSIONS}

The two researched herb species had high extraction efficiency and were not toxic to tested mice. These two species showed high antioxidant capacity, especially in the flowers of both E. mollis and E. scaber. The results showed that the leaves of the two species had a better inhibition of the growth of bacterial strains than other parts. E. coli was the strain most strongly inhibited by the extract of the two studied species. These species are rhizomes and live for many years, using parts such as leaves and flowers for medicinal purposes are good for application and conservation.

\section{ACKNOWLEDGEMENT}

We would like to thank Dr. Nguyen Phuc Dam (School of Education) for supporting the antioxidant experiment. Many thanks were sent to Assoc. Prof. Dr. Nguyen Trong Ngu (College of Agriculture), and Dr. Tran Thanh Men (College of Natural Sciences) who provided bacterial strains for this study.

\section{REFERENCES}

Aquino, R., Morelli, S., Lauro, M.R., Abdo. S., Saija, A. and Tomaino, A., 2001. Phenolic constituents and antioxidant activity of an extract of anthuriumversicolor leaves. Journal of Natural Products. 64(8): 1019-1023.

Budnik, L. T., Adam, B., Albin, M. et al., 2018. Diagnosis, monitoring and prevention of exposure-related non-communicable diseases in the living and working environment: DiMoPEx-project is designed to determine the impacts of environmental exposure on human health. Journal of Occupational Medicine and Toxicology. 13(6): 1-22.

Bui, T.V., Blizzard, C.L., Luong, K.N. et al., 2016. National Survey of Risk Factors for NonCommunicable Disease in Vietnam: Prevalence Estimates and an Assessment of Their Validity. BMC Public Health, 16: 498.

Campbell-Lendrum, D. and Prüss-Ustün, A., 2019. Climate change, air pollution and noncommunicable diseases. Bulletin of the World Health Organization. 97(2):160-161.

Dai Thi Xuan Trang, Lam Hong Bao Ngoc, and Vo Thi Tu Anh, 2015. Studies on antibacterial and antioxidant activities of methanolic extract from Streptocaulon juventas Merr. Can Tho University Journal of Science. 40(A): 1-6 (In Vietnamese).

Dai Thi Xuan Trang, Nguyen Thi Mai Phuong, Vo Thi Ngoc Diem and Tu Hue Quach, 2012. Studies on hypoglycemic and antioxidant activities of ethnolic extracts from Morinda Citrifolia L. in diabetic mice. Can Tho University Journal of Science. 23(b): 115124 (In Vietnamese).
Do Huy Bich, Dang Quang Chung, Bui Xuan Chuong et al.,. 2006. Medicinal Plants and Medicinal Animals in Vietnam, Vol 1. Ha Noi: Science and Technics Publishing House. Ha Noi, 1138 pages (In Vietnamese).

Do Tat Loi, 2004. Vietnamese Medicinal Plants and Herbs. Medical Publishing House, 1294 pages (In Vietnamese).

Firenzuoli, F., and Gori, L., 2007. Herbal medicine today: Clinical and Research Issues. Evidence-based complementary and alternative medicine. 4(s1): 37-40.

Gall, A., Leske, S., Adams, J. et al., 2018. Traditional and complementary medicine use among indigenous cancer patients in Australia, Canada, New Zealand, and the United States: A Systematic Review. Integrative Cancer Therapies. 17(3): 568-581.

La Dinh Moi, Tran Minh Hoi, Duong Duc Huyen, Tran Huy Thai, Ninh Khac Ban, 2005. Plant Resources of Vietnam - Bioactive Plants, (Vol 1). Agriculture Publishing House., 366 pages (In Vietnamese).

Mhamdi, B., Abbassi, F., Smaoui, A., Abdelly, C. and Marzouk, B., 2016. Fatty Acids, Essential Oil and Phenolics Composition of Silybum Marianum Seeds and Their Antioxidant Activities. Pakistan Journal of Pharmaceutical Sciences. 29(3): 953-959.

Ministry of Health, 2015. Guidelines for Pre-Clinical and Clinical Testing of Eastern Medicine. Medicines from Medicinal Materials, 42 pages (In Vietnamese).

Ministry of Home affairs (MOHA) and United Nations Population Fund in Vietnam (UNFPA), 2015. National Report on Vietnamese Youth. Ministry of Home Affairs, 74 pages.

Nguyen, Q. V. and Eun J. B., 2011. Antioxidant Activity of Solvent Extracts from Vietnamese Medicinal Plants. Journal of Medicinal Plants Research. 5(13): 2798-2811.

Nguyen Tan Dat and Nguyen Ba Tiep, 2016. Assessment of extraction efficacy and antibacterial activity of ethanol extract of Caesalpinia sappan L. against Escherichia coli. Vietnam J. Agri. Sci.. 14(9): 13681376 (In Vietnamese).

Nguyen Thi Ai Lan, Tra Lam Tuan Vu and Dai Thi Xuan Trang, 2019. Study on antioxidant Activities of methnolic extract from Pithecellobium Dulce (Roxb.) Benth. roots in induced oxidative stress Mice. Can Tho University Journal of Science. 55(1): 47 (In Vietnamese).

Oliver, S.J., 2013. The Role of Traditional Medicine Practice in Primary Health Care within Aboriginal Australia: A Review of the Literature. Journal of Ethnobiology and Ethnomedicine. 9(1): 1-8.

Parkavi, V., Vignesh, M., Selvakumar, K., Mohamed, J.M., and Ruby, J.J., 2012. Antibacterial Activity of Aerial Parts of Imperata Cylindrica (L) Beauv. International Journal of Pharmaceutical Sciences and Drug Research. 4(3): 209-212. 
Pham Hoang Ho, 2003. An Illustrated Flora of Vietnam, (Vol 2). Ho Chi Minh City: Tre Publishing, 951 pages (In Vietnamese).

Scartezzini, P., and Speroni, E., 2000. Review on Some Plants of Indian Traditional Medicine with Antioxidant Activity. Journal of Ethnopharmacology, 71(1-2): 23-43.

Tran Van Tien and Vo Thi Mai Huong, 2017. Study on antimicrobial and antioxidant activities of extract of Helicteres hirsuta Lour. In: The 7th National Science
Conference on Ecology and Biological Resources, 1496-1501 (In Vietnamese).

Vo Van Chi, 2012. Dictionary of Vietnamese Medicinal Plants. Medical Publishing House, 1541 pages (In Vietnamese).

Yam, M.F, Yam, M.F., Rusliza, B. and Mohd, Z.A., 2008. Antioxidant and Hepatoprotective Activities of Elephantopus Tomentosus Ethanol Extract. Pharmaceutical Biology. 46(3): 199-206. 